\title{
Morbilliform drug eruptions caused by trimethoprim-sulfamethoxazole
}

\author{
Daisuke Takenaka, ${ }^{1}$ Toshinori Nishizawa²
}

'Postgraduate Clinical Training Center, Fujita Health University, Toyoake, Aichi, Japan ${ }^{2}$ Department of General Internal Medicine, St Luke's International University, Chuo-ku, Japan

\section{Correspondence to} Dr Toshinori Nishizawa; nishizawa.toshinori@gmail.com

Accepted 9 September 2020

Check for updates

(C) BMJ Publishing Group Limited 2020. No commercial re-use. See rights and permissions. Published by BMJ.

To cite: Takenaka $D$, Nishizawa T. BMJ Case Rep 2020:13:e238255. doi: $10.1136 /$ bcr-2020238255

\section{DESCRIPTION}

Trimethoprim-sulfamethoxazole is a commonly prescribed antibiotic, mainly used in the treatment of urinary tract infection. Other indications included treatment of infections, such as Pneumocystis jiroveci, Toxoplasma gondii, Stenotrophomonas maltophilia and community-associated methicillinresistant Staphylococcus aureus. Although this drug is well tolerated, it often causes dermatological side effects like simple exanthems, fixed drug reaction, drug reaction with eosinophilia and systematic symptoms and Stevens-Johnson syndrome. ${ }^{1}$ Here, we describe a case of morbilliform drug eruptions induced by trimethoprim-sulfamethoxazole.

A 19-year-old Japanese woman presented to the emergency department with a chief complaint of fever and rash. Seven days prior, she had fever, low back pain and urinary symptoms, which was consistent with urinary tract infection. She was initially treated with oral trimethoprim-sulfamethoxazole $160 \mathrm{mg} / 800 \mathrm{mg}$ twice daily for 7 days. With 1 week of trimethoprim-sulfamethoxazole, she developed a diffuse maculopapular, erythematous rash. On physical examination, her body temperature was $38.4^{\circ} \mathrm{C}$. Diffuse erythema was noted over the face, neck, trunk, arms, and legs (figure 1). She had no mucosal involvement. Laboratory tests showed no evidence of eosinophilia. Kidney and liver function tests were normal. Trimethoprim-sulfamethoxazole was discontinued. On day 2, her fever subsided, and diffuse erythema gradually improved. Testing for measles and rubella IgM antibody was negative. We clinically diagnosed her as morbilliform drug eruptions, caused by trimethoprim-sulfamethoxazole. On day 7, all drug-induced erythema disappeared, without residual hyperpigmentation and desquamation.

Morbilliform drug eruptions are the most common reactions produced by drugs and account for $95 \%$ of cutaneous reactions. ${ }^{2}$ Morbilliform drug eruptions, also called exanthematous drug eruptions or maculopapular drug eruptions, present as diffuse, symmetrically distributed rashes composed of red macules and papules. ${ }^{3}$ The rash is morbilliform (meaning 'measles-like'), which often mimics the rash of measles and rubella. Japan has recently experienced a nationwide outbreak of measles and rubella among young adolescents. ${ }^{45}$ Therefore, prompt diagnosis of morbilliform drug eruption is challenging because it may appear similar to the rash seen in measles and rubella.

Morbilliform drug eruptions typically appear 4-21 days after taking the causative medications. ${ }^{4}$ Therefore, the time course of skin reactions relative

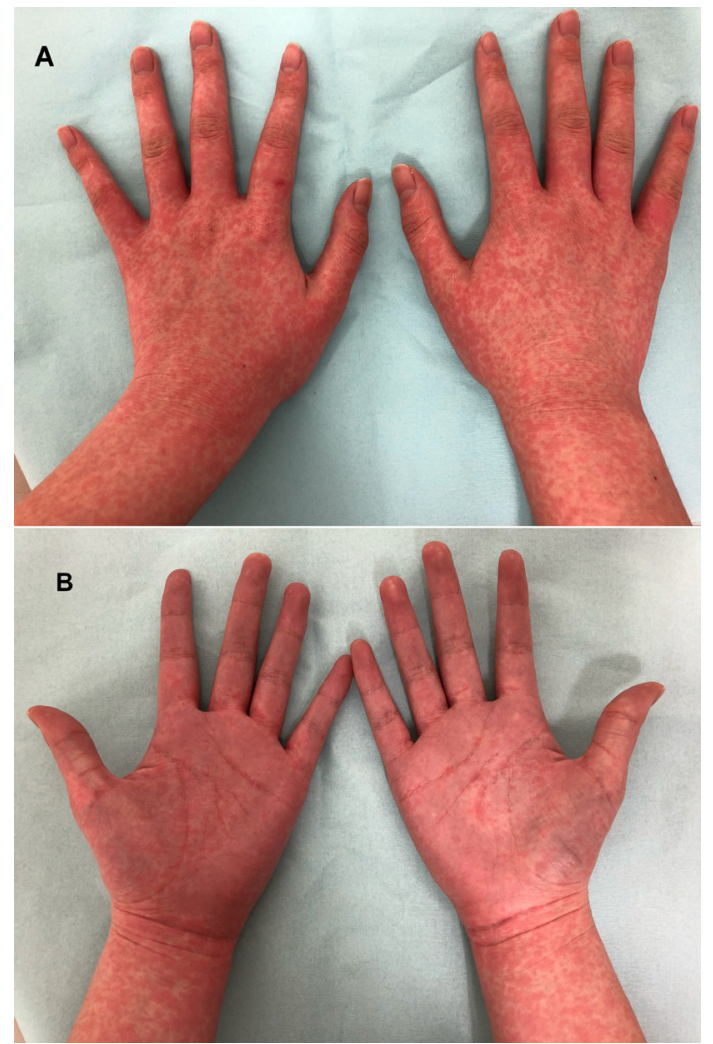

Figure 1 ( $A$ and $B$ ) A diffuse, symmetrically distributed rash composed of red macules and papules on both hands.

to the drug administration is an important clue to differentiate viral exanthems from drug-induced exanthems. Morbilliform drug eruptions reach the maximal extent within 2 days after the drug is discontinued, and fade within a week after the elimination of the drug. ${ }^{3}$ Resolution after a medication is discontinued also helps to identify the causative drug.

Associated symptoms with morbilliform drug eruptions include pruritus and low-grade fever. ${ }^{6}$ Of the 25 morbilliform drug eruptions, pruritus was

\section{Patient's perspective}

A mother's perspective : at first, we worried about viral infections, such as measles and rubella. I did not know trimethoprim-sulfamethoxazole caused drug eruptions. When our doctors explained how trimethoprim-sulfamethoxazole caused drug eruptions and when these skin lesions would fade, we were relieved. 


\section{Learning points}

- Morbilliform drug eruptions typically appear 4-21 days after taking the causative medications.

- Morbilliform drug eruptions reach the maximal extent within 2 days after the drug is discontinued and fade within a week after the elimination of the drug.

present in 22 cases (88\%) and was more severe than in rashes from other causes. ${ }^{7}$ Fever was more often present in viral exanthems (91\%) than in morbilliform drug eruptions (15\%). On laboratory evaluation, serum $\mathrm{C}$ reactive protein and absolute eosinophil count tend to be higher in morbilliform drug eruptions than virally induced skin eruptions, which might help in differentiating skin eruptions. ${ }^{8}$

Physicians should be aware of typical presentation of morbilliform drug eruptions to differentiate from viral exanthems by the time course, associated symptoms and laboratory evaluation.

Contributors DT cared the patient and wrote the report. Both authors read and approved the final version of the report.
Funding The authors have not declared a specific grant for this research from any funding agency in the public, commercial or not-for-profit sectors.

Competing interests None declared.

Patient consent for publication Obtained.

Provenance and peer review Not commissioned; externally peer reviewed.

\section{REFERENCES}

1 Ho JM-W, Juurlink DN. Considerations when prescribing trimethoprimsulfamethoxazole. CMAJ 2011;183:1851-8.

2 Gerson D, Sriganeshan V, Alexis JB. Cutaneous drug eruptions: a 5-year experience. J Am Acad Dermatol 2008;59:995-9.

3 Stern RS. Clinical practice. Exanthematous drug eruptions. N Eng/ J Med 2012;366:2492-501.

4 Mizumoto K, Kobayashi T, Chowell G. Transmission potential of modified measles during an outbreak, Japan, March-May 2018. Euro Surveill 2018;23:1800239.

5 Ujiie M. Rubella resurgence in Japan 2018-2019. J Travel Med 2019;26:taz047.

6 Korman AM, Alikhan A, Kaffenberger BH. Viral exanthems: an update on laboratory testing of the adult patient. J Am Acad Dermatol 2017;76:538-50.

7 Drago F, Rampini E, Rebora A. Atypical exanthems: morphology and laboratory investigations may lead to an aetiological diagnosis in about $70 \%$ of cases. $\mathrm{Br} J$ Dermatol 2002:147:255-60.

8 Singh S, Khandpur S, Arava S, et al. Assessment of histopathological features of maculopapular viral exanthem and drug-induced exanthem. J Cutan Pathol 2017:44:1038-48.

Copyright 2020 BMJ Publishing Group. All rights reserved. For permission to reuse any of this content visit

https://www.bmj.com/company/products-services/rights-and-licensing/permissions/

BMJ Case Report Fellows may re-use this article for personal use and teaching without any further permission.

Become a Fellow of BMJ Case Reports today and you can:

- Submit as many cases as you like

- Enjoy fast sympathetic peer review and rapid publication of accepted articles

Access all the published articles

- Re-use any of the published material for personal use and teaching without further permission

\section{Customer Service}

If you have any further queries about your subscription, please contact our customer services team on +44 (0) 2071111105 or via email at support@bmj.com.

Visit casereports.bmj.com for more articles like this and to become a Fellow 